\title{
Magnetism's Transformation from Natural Phenomenon to Literary Metaphor
}

\section{Sarasti-Wilenius, Raija S}

Brill

2020-05-25

Sarasti-Wilenius , R S 2020 , Magnetism's Transformation from Natural Phenomenon to Literary Metaphor . in F Schaffenrath \& M T S Hernández (eds) , Acta Conventus Neo-Latini Albasitensis : Proceedings of the Seventeenth International Congress of Neo-Latin Studies pÿ(Albacete 2018) . Acta Conventus Neo-Latini , no. 17 , Brill , Leiden , pp. 496505 . https://doi.org/10.1163/978900

http://hdl.handle.net/10138/330243

https://doi.org/10.1163/9789004427105_039

unspecified

acceptedVersion

Downloaded from Helda, University of Helsinki institutional repository.

This is an electronic reprint of the original article.

This reprint may differ from the original in pagination and typographic detail.

Please cite the original version. 
Magnetism's Transformation from Natural Phenomenon to Literary Metaphor

Raija Sarasti-Wilenius

Metaphors and analogies have been central to scientific thinking since antiquity; by connecting generally known ideas to something that is unknown, metaphors help scientists communicate and help people grasp complex ideas or concepts. Metaphors also move in the opposite direction. Several scientific discoveries and concepts have inspired allusions, metaphors, analogies, and symbols that eventually entered the literature of their age. In literary metaphors, concepts are often broadened and meanings are extended beyond the limits of their rigid scientific definitions, taking on lives of their own. ${ }^{1}$ Especially from the mid-seventeenth century on, the "two cultures" - that is science (factual, accurate) and literature (fictive, inaccurate) have been diverging from each other, which has brought about discussions on the proper style of scientific language and the significance and roles of truth and metaphor. ${ }^{2}$ This paper

1 Pamela Gossin, "Literature and the Modern Physical Sciences," in The Cambridge History of Science 5, ed. Mary Jo Nye (Cambridge, 2003), 91-110, there 99-100; D. R. Langslow, "The Language of Poetry and the Language of Science: The Latin Poets and 'Medical Latin',' in Proceedings of the British Academy 93 (1999), 183-225, there 198-202.

${ }^{2}$ For the much-discussed topic of significance of truth and metaphor in early modern literature and science, see Wendy Beth Hyman, 'Deductions from Metaphors: Figurative Truth, Poetical Language, and Early Modern Science," in The Palgrave Handbook of Early Modern Literature and Science (2017), 27-48, there 27-8; Mary Thomas Crane, "John Donne and the New Science," in The Palgrave Handbook of Early Modern Literature and Science (2017), 95-114. 
discusses a scientific and a literary text by an author from the second half of the seventeenth century, when the "two cultures" still overlapped in many respects and when the goal of utilizing precision and unambiguity in scientific language still needed a champion in one of the most northern universities of Europe, the Academy of Turku. ${ }^{3}$

My aim is to examine the use of magnetism as a literary metaphor in a Latin oration, Scientiarum magnes (1690) by Daniel Achrelius, Professor of Eloquence at the Academy of Turku (1679-92), then the most prominent town in the eastern part of the Swedish realm. Achrelius' predilection for magnetic symbolism derived from the idea of magnetism as a force behind a variety of natural phenomena, as explained in his natural philosophical work Contemplationes mundi (1682). ${ }^{4}$ I will seek an answer to the question of whether there was a some sort of a broader philosophical implication behind Achrelius' deployment of magnetic symbolism in Scientiarum magnes, or whether it was purely metaphorical. Before dealing with Achrelius' Contemplationes mundi and Scientiarum magnes, I will make some general remarks on scientific research into magnetism in premodern times, and on magnetic symbolism in literature, in order to provide some background to Achrelius' writings.

\footnotetext{
${ }^{3}$ Mary Baine Campbell, "Literature," in The Cambridge History of Science 3, ed. Kathrine Park, Lorraine Daston (Cambridge, 2006), 756-72, there 770.

${ }^{4}$ Achrelius' Contemplationes mundi was first written as a series of dissertations, and later published as a single volume in 1682. Jorma Vallinkoski, Die Dissertationen der alten Universität Turku (Academia Aboensis) 1642-1828 (Helsinki, 1966), Nos. 1-21.
} 
Naturally occuring magnets, called lodestones, are a form of iron oxide found in certain iron mines, the knowledge of which long predates the Christian era. The name lodestone referred to the ability of this material to indicate direction; a compass needle made of lodestone could lead you to your destination in the same way that the lodestar (the North Star, Polaris), which marks north in the night sky, could guide you on your journey. ${ }^{5}$ According to Lucretius' De rerum natura (the first century B.C), the word magnet derives from the Lydian city of Magnesia, where magnetic rock may have first been discovered or recognized. ${ }^{6}$ Another ancient source, the Naturalis historia of Pliny the Elder, tells a story about a shepherd named Magnes, who discovered a magnetic field to which the iron nails of his shoes stuck fast while he pastured his flocks on Mount Ida. ${ }^{7}$ Both Lucretius and Pliny described the basic properties of a lodestone: it draws other pieces of iron towards itself, but sometimes iron was also repelled from it. ${ }^{8}$ Since this seemed to happen for no apparent reason, the behaviour was often considered magical, and gave rise to many superstitions: magnets were thought to be useful for thieves, and women in labour, and also effective in a love potion. It was believed that they could repel sorcery, drive demons away, and even reconcile married couples. ${ }^{9}$ In the Middle Ages, the best-known experiments on magnetism were conducted in the thirteenth century by the French scholar Petrus Peregrinus de Maricourt (fl. 1269). During his service as an engineer in the army of the

${ }^{5}$ Gerrit L. Verschuur, Hidden Attraction: The History and Mystery of Magnetism (Oxford, 1996), 7-8.

${ }^{6}$ Lucretius, De rerum natura 6, 906-9.

${ }^{7}$ Pliny, Naturalis historia 36, 127

${ }^{8}$ Lucretius, De rerum natura 6, 910-1064; Pliny, Naturalis historia 36, 126-7.

${ }^{9}$ Verschuur, Hidden Attraction (see above, n. 5), 21; Duane H.D. Roller, The De Magnete of William Gilbert (Amsterdam, 1959), 27. 
King of Sicily, Charles of Anjou, he described the properties and usage of lodestone in a letter, Epistola de magnete, to his soldier friend. ${ }^{10}$ However, several misconceptions and superstitions still surrounded magnetism three centuries later, when the English physician William Gilbert's (1544-1603) serious experimental investigations took place. Gilbert's work De magnete, published in 1600, reported his greatest insight: that the earth itself was magnetic. ${ }^{11}$

Gilbert's work generated many experiments and much speculation about magnetism during the first half of the seventeenth century. ${ }^{12}$ One of the outcomes of this exploration was a movement called magnetic philosophy, whose advocates believed that magnetic forces explained a wide range of natural phenomena. For example, both the supporters of the earthcentred and sun-centred structures of the universe drew upon magnetism for inspiration. ${ }^{13}$ The principal sources of information on magnetism in Daniel Achrelius' Contemplationes mundi were the Jesuit polymath Athanasius Kircher (1601-80) and his collaborator Kaspar Schott (160866)..${ }^{14}$ German by birth, Kircher settled down at the Jesuit college in Rome in 1633 and

10 Roller, The De Magnete of William Gilbert (see above, n. 9), 39-42.

11 Roller, The De Magnete of William Gilbert (see above, n. 9), 93-4; Verschuur, Hidden Attraction (see above, n. 5), 19.

12 Martha Baldwin, “Kircher's Magnetic Investigations," in The Great Art of Knowing: The Baroque Encyclopedia of Athanasius Kircher, ed. Daniel Stolzenberg (Stanford, 2001), 17-36, there 27.

13 Verschuur, Hidden Attraction (see above, n. 5), 31.

${ }^{14}$ In addition to Kircher and Schott, Contemplationes mundi presented ideas compiled from various other sources, such as Daniel Sennert, Johannes Sperling, Bernhard Varenius, Isaac Vossius, Antonius Le Grand. Maija Kallinen, "Daniel Achreliuksen teos Contemplationes 
concentrated on his ambition to synthesize all known fields of knowledge. The title of the recent work edited by Paula Findlen, Athanasius Kircher. The Last Man Who Knew Everything, illustrates his pursuits very well. ${ }^{15}$ In addition to the magnetic studies contained in his works on astronomy, botany, geology, medicine, and theology, he also wrote two books directly addressing magnetism, his first book Ars magnesia (1631) and the later Magnes sive de Arte Magnetica (Rome 1641). Kircher went beyond most natural philosophers and scientists of his age, such as Francis Bacon, René Descartes, Galileo Galilei, and Isaac Newton, in seeing the magnet as the key to understanding all other fields and phenomena. ${ }^{16}$ Kircher's theory of universal magnetism was criticized by several contemporary scientists, who did not regard Kircher's explanations as scientifically credible. Indeed, Descartes famously declared that Kircher was more of a charlatan than a scholar. ${ }^{17}$

Daniel Achrelius' Contemplationes mundi was a typical natural philosophical work of its age, studying the material world and its changes, and dealing with, amongst other things, cosmography, meteorology, the earth, minerals, plants, and animals, including human beings. In

mundi - sen lähdepohja ja tulkintaa," Minerva. Aate- ja oppihistorian vuosikirja 2 (Oulu, 1991), 3 140 , there $15-22$.

15 Athanasius Kircher. The Last Man Who Knew Everything, ed. Paula Findlen (New York, 2004).

${ }^{16}$ Baldwin, "Kircher's Magnetic Investigations" (see above, n. 12), 17.

${ }^{17}$ Paula Findlen, "Introduction. The Last Man Who Knew everything ... or Did He?," in Athanasius Kircher. The Last Man Who Knew Everything (see above, n. 15), 1-48, there 22; René Descartes, Correspondence 3, ed. Charles Adam, Gérard Milhaud (Paris, 1936-63), 803. 
addition, it also addressed metaphysical questions, seeking the universal causes of phenomena. ${ }^{18}$ In his work, Achrelius repeated the facts about magnetism that were generally known in his time, such as its power to attract iron objects, its polarity, and its utility to navigators and cartographers in the form of the compass; but he was also fascinated by the supposed mysterious powers of magnets, and went much further in his remarks. ${ }^{19}$ He claimed that a wide variety of natural phenomena could be best explained as the result of occult magnetic powers. One of these was a botanical phenomenon known to botanists today as phototropism: Achrelius argued that a plant inclined toward its light source in the same way that a lodestone always sought to situate itself parallel to the axis of the Earth. Based on this notion, Kircher presented the design for a sunflower clock in his Magnes. ${ }^{20}$ Another botanical example taken from Kircher - Achrelius himself had hardly seen a palm tree in its natural habitat - concerns the love of male and female palm trees caused by the force of sympathy. ${ }^{21}$ This idea is also

${ }^{18}$ Brian W. Ogilvie, "Science and Medicine," in The Oxford Handbook of Neo-Latin, ed. Sarah Knight, Stefan Tilg (Oxford, 2015), 263-77, there 263; Kathrine Park and Lorraine Daston, "Introduction. The Age of the New," in The Cambridge History of Science 3, ed. Kathrine Park, Lorraine Daston (Cambridge, 2006), 1-18, there 4.

${ }^{19}$ Kallinen, “Daniel Achreliuksen teos Contemplationes mundi” (see above, note 15), 94.

${ }^{20}$ Daniel Achrelius Contemplationes mundi (Aboae, 1682), 286-8; Athanasius Kircher, Magnes sive de arte magnetica (Coloniae Agrippinae, 1643), 645; Baldwin, "Kircher's Magnetic Investigations" (see above, n. 12), 30 .

21 Achrelius Contemplationes mundi (see above, n. 20), 228: “[...] inter palmam marem \& faeminam tale intercedere amoris conjugium, ut veluti veneris intellectus ijs insidere videatur. Quippe mas solus crescens contabescere dicitur, at vero si juxta illum foemina fuerit plantata, hanc amoris 
depicted in a contemporary emblem: two palm trees bending their heads towards each other (over a river), with the motto vivite concordes. ${ }^{22}$ The strong connection between male and female palm trees is comparable to a harmonius marriage; a solitary male tree fades away, but if it is planted next to a female tree then both flourish.

The behaviour of lodestones provided many opportunities for their use as a symbol or literary metaphor. Magnetism was used to describe both the process of attraction or repulsion and the sympathy-antipathy relationship. In the index of literary symbols provided in the Latin translation of Filippo Picinelli’s Mondo simbolico (Venice, 1635), the symbolic meanings of magnetism associated with God, God's will, mercy, providence, Christian life, fate, contemplation, conformity, etc. are in the majority. Moreover, magnets were commonly used as symbols for many other things, such as true love, friendship, peace, unity, constancy, but also things that stand for less desired aspects or qualities, such as worldly pleasures, harmful overriding passions, and extravagance. ${ }^{23}$ Magnetic symbolism also appeared in iconography. An emblem with the motto 'the mind remains unmoved' (mens immota manet) referenced the property of lodestones always pointing to the north; the connection between the image and the pignore exhilaratam, uberi foetura impraegnat, amboque jucundissime \& genialiter vivunt." Kircher, Magnes (see above, n. 20), 630-1.

22 Jacob Cats, Alle de wercken 1 (Amsterdam, 1658), 108.

23 "Index rerum notabilium quae in mundo symbolico reperiuntur," in Mundus symbolicus in emblematum universitate formatus, explicatus et tam sacris quam profanis Eruditionibus ac Sententiis illustratus. Idiomate Italico conscriptus a D. Philippo Picinello [...] nunc vero in latiam traductus a R.D. Augustino Erath (Coloniae Agrippinae, 1681), s.v. magnes. 
motto is explained as follows: "One says that the Magnet moves iron through its internal power and hence continuously shows sailors the way. For it always looks securely, without wavering, at the pole star. In this way it depicts the passage of time and warns us in various ways. If only our mind remained so directed towards heaven, unmoved, and would not suddenly waver over fickle misfortunes." 24

Achrelius employed magnetism as a literary device in the epideictic speeches he wrote and delivered at various social functions, often in the name of the Academy of Turku. In this connection, I deal with his rhetorical masterpiece, entitled Scientiarum magnes, dedicated to the Swedish King and Queen, Charles XI and Ulrica Eleonora, when celebrating the King's thirtyfifth birthday and the fiftieth anniversary of the Academy of Turku in $1690 .{ }^{25}$ Connected to a wide variety of subjects, the symbol of the magnet runs through the whole speech, tying its different parts together. The word magnes itself is often highlighted in the text through the use of capital letters or a larger font. The most important idea presented there, the magnetism of the sciences, was already explained in the invitation to the delivery of the speech (the academic programme): the magnetism of sciences is drawn into the human head by divine plan, and

\footnotetext{
24 Johannes Sambucus, Emblemata (Antverpiae, 1564; Budapest, 1982), 84: “Dicitur interna vi Magnes ferra movere/ Perpetuo nautas dirigere inque viam./ Semper enim stellam firme aspicit polarem./ Indicat hac horas, nos varieque monet./ Mens utinam in caelum nobis immota maneret,/ Nec subito dubiis fluctuet illa malis."

${ }^{25}$ In printed form, the speech comprises 70 pages in quarto size.
} 
examines the poles of the Earth and the pole of Eternity by means of both human abilities and scientific methods and principles. ${ }^{26}$

The obvious discrepancy between the modest appearance and the inner powers of lodestones introduces the passage that exemplifies the title. Already in Contemplationes mundi, Achrelius had quoted verses of the late antique poet Claudius Claudianus' poem entitled Magnes, probably cited from Kircher's Magnes, pointing out that even if the unpretentious looking lodestone was not used to adorn precious and beautiful jewellery, its powers make it superior to any other stone. ${ }^{27}$ This also applies to the so-called magnetism of the sciences; it is not valued by uncultured, uneducated, and hypocritical people, but it nevertheless embraces all the knowledge and secrets that are meaningful to humankind. The passage, structured around the repetition of the phrase 'with its repulsion and attraction' (Hujus attractu et repulsu), specifies various sciences and disciplines as exemplifying this trait, including theology, law, medicine, moral philosophy, eloquence, and history. Through the force of the magnetism of the sciences, the prudent mind

${ }^{26}$ Daniel Achrelius, Scientiarum magnes (Aboae, 1690, henceforth SM), academic programme composed in lapidary style: "Vix ratio concipere/Vix humana eloquentia/ potest exponere/ Grandia consilia coeli! qvae unice/ In exiguo humano cranio/ pinxerunt/ MAGNETEM SCIENTIARUM./ Ille/ Judicio, Ingenio, Meditatione, Industria/ Tangit/ Norma Artium,/ Scientia solida,/ Prudentia cauta/ Indagine sapienti/ Polos mundi; polum aeternitatis.” ${ }^{27}$ Claudius Claudianus, Carmina minora 29,10-5: “ [...] lapis est cognomine magnes/ decolor obscurus vilis. non ille repexam/ caesariem regum, non candida virginis ornat/ colla nec insigni splendet per cingula morsu/ sed nova si nigri videas miracula saxi,/ tunc pulchros superat cultus [...]"; Kircher, Magnes (see above, n. 20), 1-5. 
is freed from earthly affairs and approaches heaven, justice chases away fraud and injustice, medicine suppresses diseases, virtues flourish, and eloquence and history are able to promote the good in the world..$^{28}$

After the introduction, all the disciplines taught and studied at the Academy of Turku are dealt with individually; and each of them is called a magnet, or claimed to have magnetic powers. For

${ }^{28} S M$ (see above, note 26), 13-8: "Inter saxa numeratur MAGNES lapis nigricans et vilis; ille miserculus, non pendet de auribus Reginarum, non ornat eburnea Virginum colla, nullo auro unqvam incrustatur. Gaudet tamen hoc dominio, ut ambos mundi Polos liget, metallorum praestantiam superet, nitidam gemmarum puritatem longe post se relinqvat, illud orbis speculum, ille ingeniorum cor! illa Sapientium impenetrabilis profunditas. Idipsum de Scientiarum Magnete licebit dicere: qvamvis in nullo sit pretio apud aulas barbaricas, apud collegia ineptorum, apud Scribarum et Pharisaeorum mensas, tamen qvidqvid Sacramentorum curiosis mentibus et oculis subjicit natura, qvidqvid Virtutum catenam intrat et decet, qvidqvid in Regiminis Throno arcani latet, omnia in se conclusit SCIENTIARUM MAGNES. Hujus attractu et repulsu segregat se mens cordata a terrenis sordibus et alligatur coelo. Hujus attractu et repulsu iniqvitatis dolos in exilia pellit justitia. Hujus attractu et repulsu detruncat agmina morborum medicina. Hujus attractu et repulsu florescit Fortitudo, temperantia, bonorum copia. Hujus attractu et repulsu sonant cordata eloqvia, svavis lyra, alta Historia, qvae veritatis calamo orbi dant modulos, dant fercula, dant modulos, imo aperiunt ostia per qvae intramus in sacros Heroum consessus indeqve egredimur optimis instructi exemplis, malorum casu admoniti. Tantum valet hoc Regnum ornamentum, hic Procerum Sol, hoc doctorum lumen, hic ductor certissimus, SCIENTIARUM MAGNES!” 
example, mathematics is "the true imitator (simia) of God, solid foundation of architects and faithful magnet of clever inventions." 29 Law, as it is practiced in Finland, is "just and incorrupt, a magnet of impartiality." 30 God has given humans the art of medicine, which "heals and prevents diseases with its magnetic forces." 31 The passage closes with a rhetorical apostrophe, addressing Finland, which is encouraged to rejoice over the Academy of Turku as a manifestation of divine love: everything about the Academy is healthy (sana), pure (casta), and glorious (gloriosa); it is a magnet that is unrivalled. ${ }^{32}$ The atmosphere of the Academy and relations between colleagues are described as follows: "We do not lose our temper when contradicting what our colleagues say." 33 However, the minutes of the Academic Senate tell us a different story; the professors' conflicting interests gave rise to frequent quarrels, reproaches,

${ }^{29}$ Ibid., 31: "Haec est Dei simia, architectorum basis, curiosarum inventionum fidelissimus

\section{MAGNES."}

30 Ibid., 33: "Talis est Finlandiae justitia, non elegit dolosos congressus, non fictam osculatur amicitiam, non epulis flectitur; totus in se recurrit castus, purus, solidus, aeqvitatis MAGNES, MAGNES inquam \& tutela bonorum, malorum pavor, curiarum ATLAS.”

31 Ibid., 32: "[...] divinam miramur bonitatem, qvae tot vexationibus, tot cruciatibus clandestinis, mortis spiculis, uncis \& corvis immensam \& vere Magneticam contraposuit remediorum copiam.”

32 Ibid., 49-50: “Gaude ergo Finlandia, cui tantus illuxit amor! te beatam praedicabunt populi [...]. omnia sana! omnia casta! omnia gloriosa! radix sativa, stolon praegnans rami foecundi, messis uberrima, fructus aethereus, MAGNES INCOMPARABILIS."

33 Ibid., 49: "non contradicendo in collegiis exardescimus; non in petitione honorum eruditionem ac merita calcamus pedibus, jactantiis, pecunia." 
complaints, and accusations, in which scientific issues became entangled with private affairs. Achrelius himself became involved in such incidents several times; for instance, he was once accused of wounding the honour of the Bishop of Turku through one of his writings, and was dismissed from the Academy for some time. ${ }^{34}$

Since Scientiarum magnes also celebrated the thirty-fifth birthday (and thirty years of rule) of Charles XI, (King of Sweden 1660-97), the symbol of the magnet is also linked to the King and Queen. Charles XI and Ulrica Eleonora are praised as being "the magnets of the Swedish empire, heroes of victories and swans of peace." 35 Achrelius used the swan, a symbol of peace and tranquillity, because after the Scanian War, which ended in 1679, Charles indeed managed to maintain the peace for the remaining twenty years of his reign.

Aside from the sciences, the Academy, the King and Queen, and a few other subjects, the remainder of the references to magnets in Scientiarum magnes relate to Christian religion and the Christian way of life. In a navigation metaphor, Jesus is called "the bow, stern, magnet, and

${ }^{34}$ Raija Sarasti-Wilenius, "A Finnish Master of Latin oratory: Daniel Achrelius," in A History of Nordic Neo-Latin Literature ed. Minna Skafte Jensen (Odense, 1995), 321-31, there 321.

35 SM (see above, note 26), 63: "Talis est CAROLUS XI cum sua ULRICA, imperii MAGNES, Victoriarum Heroes, Pacis Cygni.” In Christoph Lackner's Coronae Hungariae Emblematica descriptio (1612), which describes royal virtues, lodestone stands for the power of virtue. Agnes Kusler, “ 'Maiestatis Hungariae Aquila’: Christoph Lackner and the Hieroglyph of the Habsburg Eagle" in Emblems and the Natural World ed. Karl A.E. Enenkel, Paul J. Smith (Leiden, 2017), 419-53, there, 427. 
anchor of our faith." 36 The analogy is clearly the use of lodestones in the compass needle of ships. God is referred to as the magnet of eternity. ${ }^{37}$ The speech ends in a wish (votum) for an eternal life in Heaven with the angels, prophets, and apostles, and before the magnet of eternity, that is God. ${ }^{38}$

In a time of orthodox Lutheranism and heated theological debates at Turku, was it not a form of heresy to deem God a magnet? In seventeenth-century natural philosophy, it was not unusual to use a magnet metaphor as a rhetorical device to explain religious teachings; the lodestone's attraction to iron was considered analogous to Christ's attraction to his disciples through divine love. ${ }^{39}$ However, natural philosophers did not usually go so far as to describe God as a magnet. Kircher, however, did; he claimed that God was the central magnet of the universe, and that magnetic forces were God's means to keep the universe in order. ${ }^{40}$ In his Contemplationes mundi, Achrelius tried to avoid questions related to controversial issues in theology. Kircher's wide-ranging ideas about magnetic forces influenced Achrelius' natural

36 SM (see above, note 26), 43: “nostrae fidei prora, puppis, MAGNES, anchora, DEI FILIUS.”

${ }^{37}$ Ibid., 16: “ad DEUM DEORUM, Maximum, ad UNICUM \& SOLIDUM AETERNITATIS MAGNETEM.”

38 Ibid., 70: "ultimum votorum, ut Tecum, o sanctissima TRINITAS! cum beatis angelis, cum Prophetis, cum Apostolis, cum beatorum coetu, coram Aeternitatis MAGNETE [...] concelebremus JUBILAEUM in secula seculorum."

39 Ogilvie, "Science and Medicine" (see above, n. 18), 265-6.

40 Baldwin, "Kircher's Magnetic Investigations" (see above, n. 12), 34-5. 
philosophical theories; however, in that context, describing God as a magnet would have meant crossing a distinct line. Yet, addressing God as a magnet in the rhetorical context of the Scientiarum magnes was an entirely different matter. It was a literary device examplifying the inflated Baroque style prevailing at the time. It was simply a metaphor that did not provoke the academic audience, not even the most meticulous professors of theology, who readily remarked on any issue that might have been dubious from the point of view of orthodox Lutheranism.

Achrelius' oration Scientiarum magnes is one example of the literary works that drew their inspiration from magnetic studies in the early seventeenth century, when such references were in vogue. ${ }^{41}$ The magnet was already an established trope in Neo-Latin literature, serving several purposes. In his oration, Achrelius fully exploited the strong impression that the phenomenon of magnetism made on the imagination, elaborating on the symbol as the cohesive thread tying together different parts of the speech. In the most important section, the praising of the sciences, the symbol is used to illustrate that just as lodestone attracts iron, so does intellectual curiosity inspire human minds to examine the world and the achievements of the preceding scientists, in turn encouraging the scientists of subsequent generations. This idea resembles Angelo Poliziano's use of the magnet as a metaphor for the divine inspiration of poets; he describes how poetic inspiration is transferred from one poet to another forming one long chain, similar to a chain of iron rings attracted to each other by magnetic force. ${ }^{42}$ Although

${ }^{41}$ Basilius Plinius' (1540-1605) poem Carmen de magnete (Augustae Vindelicorum, 1603), praising the city of Riga, is another example that used the magnet as a common thread of a literay work. ${ }^{42}$ Angelo Poliziano, Ambra 14-7 and Nutricia 193-6. Charles Fantazzi, Angelo Poliziano Silvae (Cambridge, Massachusetts, 2004), 174. 
Achrelius says that it is a divine force that impels the intellectual curiosity, it is unlikely that he is suggesting that there is a some sort of general divine magnetic force similar to stoic pneuma/spiritus.

Achrelius was fascinated by Kircher's theory of universal magnetism as an explanation for a wide range of natural phenomena, but as a whole his natural philosophy was a compilation of ideas from various sources rather than a consistent theory about the origin and nature of the universe. His use of magnetic symbolism in Scientiarum magnes should be seen purely as a metaphor, which, like several other metaphors adopted from science, enjoyed a much broader freedom of expression in literary than in scientific contexts.

University of Helsinki 